\title{
Right to Lawful Defense as a Reason for Justification "Comparative Study"
}

\author{
Dr. Maen Fathi Mesmar \\ Assistant Professor / Police College - Qatar
}

\begin{abstract}
The purpose of this research is to identify the right to lawful defense as a reason for justification by identification of the concept of lawful right to defense and its basis in Qatari and Jordanian and laws, and conditions of the right to lawful defense as well as the restrictions of right to lawful defense, and to identify how to prove the right to lawful defense. The researcher used the inductive methodology and analytical comparative methodology. This research was divided into four topics. First topic: Concept and basis of lawful defense. Second topic: Conditions of lawful defense. Third topic: Restrictions of lawful defense and rule of infringement thereof. Fourth topic: Proving the right to lawful defense.
\end{abstract}

DOI: $10.7176 / \mathrm{JLPG} / 84-06$

Publication date: April $30^{\text {th }} 2019$

\section{Introduction:}

Lawful defense is a reason for permission; that is, it adds to criminalized act that was committed by the person lawful status, and brings it out of the scope of criminalization. From the context of this statement, we find that the provisions of criminalization law are not absolute and that they are subject to restrictions that narrow their scope. Legislature aims by setting the provisions of protection of specific social interests is very important. It stipulates criminalization of those acts, but it may assess the benefit that would inure to society in case of non-punishment that exceeds the benefit that inures to it in case of punishment thereof in certain circumstances. It can decide to consider it lawful in such circumstance, although it is governed by the provisions of criminalization.

It is stipulated for materialization of the right to lawful defense that an act is committed and that the act threatens illegal danger and case that threatens with commission crime against self or some crimes of usurpation of property which is defined by law. Defense shall be required and shall be proportional to the danger which is threatened by offense. Whoever satisfies the conditions of lawful defense shall comply with the restrictions defined by law and shall not infringe them. Satisfaction of the case of lawful defense and completion of all its conditions shall result in permission of the act of defense; that is, it becomes lawful act and liability shall not be proved against perpetrator on the civil or penal level. However, defender shall prove that these conditions are satisfied and that the court is satisfied with existence of justification for use of the right to lawful defense.

Within the scope of this research, we will handle one of the reasons that make the criminalized act to be justified and not penalized, which is the right to lawful defense. Therefore, it is known that this right is a key right that will authorize man to defend himself or others or his property or property of others using force required for lifting any illegal offense which would occur or to prevent continuity of act, if it actually happened.

\section{Problem of the research:}

Reasons for permission are characterized by objective nature since satisfaction of a cause of them results in removal of the criminal status of perpetrator, and its effect shall extend to the act not to the person of perpetrator. Therefore, its effect shall extend to every person who contributed to the crime, and when any man faces danger that threatens him or threatens his property, it is intuitive that this person have reaction to bar this danger from him. The act committed by man for self-protection or property or others protection to deter offense law guarantees this disposal and considered it to be reason for justification. It was authorized but within specific conditions, so problem of the research shall be coined by the following main question: What is the definition of the right to lawful defense as a reason for justification?

This research raises many questions as follows:

1. What is the concept of right to lawful defense and its basis in Qatari and Jordanian laws?

2. What are the conditions for the right to lawful defense as a reason for justification?

3. What are the restrictions of the right to lawful defense?

4. How can the right to lawful defense be proved?

\section{Importance of the research:}

Importance of this research lies in the topic that will be addressed by the research, which is the right to lawful defense as one of the reasons for justification which were handled by Qatari and Jordanian legislature, in addition to affidavit of the researchers in the field of law on the right to defense and conditions that shall be satisfied in the right to lawful defense. 
In addition, importance of the research lies in its provision of the theoretical side in studies and research that handled the right to lawful defense in the State of Qatar in particular, and the cognitive enrichment that will be added by this study to the legal studies in the State of Qatar and Hashemite Kingdom of Jordan, due to scarce studies and references that address the study the matter of this topic, and because this topic is recent, and the critical importance of the right to lawful defense, which requires study and analysis of this topic objectively and scientifically.

In addition to addressing the rulings of Qatari Court of Cassation in this respect and comment on them, to determine the methodology that was adopted by the Qatari Court of Cassation on infringement of the limits of lawful defense to be scientific research and reference to be used by researchers in this topic.

Justifications for choice of the topic:

1. The right to lawful defense is one of the important topics in jurisdiction of the penal code because of its direct relation to the life of people for protection of self, honor and property.

2. Personal desire for further knowledge of the topic of the right to lawful defense and knowledge thereof and use and utilization thereof.

3. Due to society's ignorance of the right to lawful defense, this recalled attention of the researcher to determine the judgments, conditions and cases of defense.

\section{Methodology of the research:}

This study relied on the inductive methodology by inducting all legal provisions and judgments related to this topic, in addition to the analytical and comparative methodology, since it will analyze and discuss those topics and statements of jurists. Therefore, it shall be compared to determine the sides of deficit for avoidance of them, or to show their advantage.

\section{Research plan:}

To achieve the objective of this research, it was divided into four topics: First topic: Concept and basis of lawful defense. First theme: Concept of the right to lawful defense. Second theme: Basis of the right to lawful defense. The Second topic handled: Conditions of lawful defense. First topic: conditions of offense. Second theme: conditions of the act of defense. Third topic: Restrictions of lawful defense and rule of infringement thereof. First theme: Restrictions to lawful defense. Second theme: Rule of infringement thereof. Fourth topic: Proving the right to lawful defense. Fifth theme: Proving the right to lawful defense. Second topic: Effect of the right to lawful defense.

\section{What is the right and basis of lawful defense}

Man's defense of himself against the threats that he may encounter is normal and arises out of the human instinct. For this purpose, legislations in all ages agreed that right to lawful defense be considered reason that prevents penalty, even if the basis of this defense is different. To clarify this, this topic was divided into two themes:

\subsection{Concept of the right to lawful defense:}

General legal principles authorize whoever defends himself or others or his property or that of others to use the force required to deter any illegal offense that may be committee or prevent continuity of its occurrence, if it actually occurred. Law always prefers protection of the victim's interest over the perpetrator's interest because the victim's interest is more worthy of care and attention, so crime of defender becomes authorized behavior ${ }^{(1)}$. According to this right to lawful defense, the victim is granted the right to killing, if killing is required and necessary to save his life. Otherwise, he would be the killed and shall be granted right to battery, if battery is required for defending him. Otherwise, he would be the battered. ${ }^{(2)}$

Opinions of legal criminal jurisprudence on definition of lawful defense varied, and some penal legislation in Arab countries multiplied. Those penal legislations stipulated definition of lawful defense. Even though most Arab legislations handled the right to lawful defense and defined its conditions, they didn't define it. This approach was adopted by Qatari legislation in penal code No (11) of 2004, and Jordanian legislation in law No (16) of 1960, as amended.

Key juristic definitions contained in this respect include: "Use of power required to bar present illegal danger that threatens abuse of right protected by law." (3)

It also defined the right to use of necessary force prescribed by law for interest of defender to deter present office on him or on his property, self, others or property. ${ }^{(4)}$

\footnotetext{
${ }^{1}$ Ahmed Abdullah Beshir: General Criminal Law, Part I, in Crime, 1998, p. 100.

2 Samir Alia: Fundamentals of penal code, General Section, Comparative Study, University Establishment for Studies, 1996, p. 253.

${ }^{3}$ Mahmoud Naguib Hosny: Explanation of Penal Code, General Section, edition of 1977.

${ }^{4}$ Awad Mohamed Awad and Suleiman Abdelmonem: General Theory of Criminal Law, $5^{\text {th }}$ edition, University Establishment for Studies, Publishing and Distribution, Beirut, 5000, p. 525.
} 
It was defined by another as use of force required for encounter of the danger of present offense is invalid and not raised to threaten damage that may inflict right protected by law. ${ }^{(1)}$

Qatari legislature expressed the right to lawful defense in article (49) and stipulated that, "There would be no crime of perpetrator is committed by use of the right to lawful defense." (2) Jordanian legislature handled the right to lawful defense in article $60 / 1$ of Jordanian penal code by stipulating that it is right. Jordanian legislature handled in the provisions of articles (341 and 342) the various judgments of lawful defense. However, these were within the provisions of excuse in killing which related to felonies and misdemeanors that may be committed against man. From this standpoint, researcher finds that Qatari and Jordanian legislatures handled the conditions that shall be satisfied in the crime of lawful defense. ${ }^{(3)}$

Therefore, the right to lawful defense is a general right prescribed by law against all, and is met by people with respect. Materialization of this right makes the committed act permitted and lawful, and its perpetrator shall not be held liable for it. This is further clarified when we handle the basis of lawful defense.

\subsection{Basis of the right to lawful defense:}

Jurisdiction and legislation different on the basis of the right to lawful defense. Some consider it case of moral intimidation because of the state of horror that inflicts defender in the instinct of preference of survival, which makes him irresponsible. ${ }^{(4)}$

However, this opinion wasn't successful, because the offense suffered by defender is not required to deprive him of his freedom of choice, in addition to the fact that the right to defense is permissible, even if offense didn't threaten the life of defender and that it extends only to his property.

It is widely believed that the idea of performance of duty diligently is based on maintenance of rights of social value, and this opinion is opposed by the fact that every legal duty shall be encountered with penalty for not performing it. Law didn't make objection to defense reason that gives rise to any penalty. A third team considered that the right to lawful defense legal authorization by the state to individuals to prevent offense of rights which are protected by penal code. This opinion is criticized because the state's right to prevent crimes can't be subject to authorization and delegation because it is related to public order and waiver shall not be admitted. ${ }^{(5)}$

Some tried to consider the right to lawful defense type of necessity, which was adopted by Jordanian penal code where article (60) stated in the first and second paragraphs and (341) of penal code on the basis that it is right to be used when necessary. Qatari legislature stipulated case of necessity when it was listed within chapter five which is titled, "Prohibitions on liability". It stipulated in article (55), paragraph two, that: "The following persons shall not be criminally liable: Whoever commits an act that he was forced to commit by necessity to protect himself or others from gross imminent danger that inflicts self or money, unless his will has input in prevention thereof. These two cases require that perpetrator can't deter danger by any other means, and that the act committed by him is to the extent required for barring the danger and is proportional to it."

Jordanian and Qatari legislatures appear to have adopted the approach that was taken by denial of penal liability of the person who committed the crime. That is, it is considered one of the prohibitions of criminal liability. This approach is corroborated by the researcher since, in fact, necessity is a condition that surrounds the person for reason uncontrollable by him and this case may result in the affected party's commission of crime for barring of damage to remove danger that may inflict him, provided danger is gross.

Whereas it is required for establishment of the case of lawful defense that defender has suffered danger that results from offense; that is, illegal act so that the defender's defense be directed to the offender, the danger that he commits in case of necessity is required in terms of the fact that it shall be gross and shall result from an act of nature or act that wasn't criminalized by law in the way that defense of the party in case of necessity is directed towards innocent person. This is in terms of conditions. Concerning consequences, the right to lawful defense is another reason for justification of act and authorization thereof. Therefore, all types of penal or civil liability shall be removed. In case of necessity, criminal liability shall be removed but civil liability shall for the illegal act that he committed by the person in case of necessity shall remain for removal of danger in the innocent person. ${ }^{(6)}$

Some tried to consider lawful defense reason for permission that strips the act the status of crime in the way that permits all to directly assume deterrence of every offense to prevent its occurrence or continuity, by every act which is required and suitable, even if that act itself is criminal. ${ }^{(7)}$ This opinion was adopted by most Arab

\footnotetext{
${ }^{1}$ Mohamed Sobdy Negm: Penal Code, General Section General Theory of Crime, $1{ }^{\text {st }}$ edition, Dar Al Thaqafa for Publishing and Distribution, Amman, Jordan, 2000, p. 140.

${ }^{2}$ Qatar Penal Code, No (11) of 2004.

${ }^{3}$ Nezam Tawfiq Al Magaly: Explanation of Penal Code, General Section, Dar Al Thaqafa for Publishing and Distribution, 2005, Jordan, p.164.

${ }^{4}$ Mahmoud Naguib Hosny: Explanation of Penal Code, General Section, Dar Al Nahda Al Arabia, 1989, p. 317.

${ }^{5}$ Ali Hussein Al Khalaf, and Sultan Abdulkader Al Shawy: General Principles of the Penal Code, 1982, Ministry of Education and Scientific Research, Baghdad University, p. 27.

${ }^{6}$ Mohamed Zaki Abu Amer: Penal Code, General Section, Dar Al Gamaa Al Gadida for Publishing, 1996, 315.

7 Ibid, p. 321
} 
legislatures that considered lawful defense right that may be used in case its conditions are satisfied. Jordanian legislature stipulated in article (60/3) that, "If there is infringement committed $n$ defense, perpetrator of crime may be exempted of penalty in the conditions set forth in article (89)" which states that, "Perpetrator shall not be punished for the act that necessity forced him to do in the same time to defend himself or others or his property or that of others, as gross inevitable danger that he didn't cause with the intention of condition that act is proportional to danger." Qatari legislature in penal code No (11) of 2004 AD stated in article (49) that, "There shall be no crime if act is committed by use of the right to lawful defense". There is another opinion which corroborates the aforementioned opinion that considered lawful defense to be right and had its logical and acceptable justification since it considered lawful defense situation imposed by mental, social and instinctive logic. This logic stipulates that man can't bear any offense, and it is assumed that offense is against man himself, or by help of others, on the offense and shall stop it even if this required abuse, wound or even killing of offender, and that offender by his offense arouses the victim's reaction. It is he who starts the offense and shall bear the results of his assault.

It was said in another opinion that permission of the act of offense in use of the right to lawful defense is attributed to the idea of compensation and replacement of self-defender or others in place of society in satisfaction of the right to punishment since offense of offender is denial of law and defense of defender is denial of that denial. Negation of negation is affirmation, because this analysis can lead to considering defender as if he is society. If he overused his right to defense, penalty may not be imposed on him, which is opposite to the solution which is taken for granted in almost all legislations, because right of the state to punishment remains right of the state which shall not be replaced by any person and shall be used by the state even against defender if defender exceeded the limits of his right to defense. What is right is that exposure to defender proves absence of police protection, and right to lawful defense is only means for treatment of that absence so defender shall have the right to prevent offense against him or continuation therein. ${ }^{(1)}$

Some considered right to lawful defense to be right, and based this on that relief of penalty in lawful defense is based on two ideas: one of them is that defense is a right that can permit whoever commits it so it shall not be described as crime. The second is that it is excuse that prevents penal liability and doesn't remove from the act the status of crime, even though it abates liability of perpetrator. ${ }^{(2)}$

Advocates of realistic school believe that lawful defense is right because its legal and social consequences and in self-defense there is defense of society. Considering the right to lawful defense as only deterrence of liability, it is attributed by some to the idea of conflict of interests and cast majority of it. That is, if two interests are in conflict so that retention of one of them requires sacrifice of the other, public interest requires sacrifice with interest of lower value and offense by nature undermines the offender's right unless he wastes this right before the victim. For this purpose, the latter shall not be accountable. ${ }^{(3)}$

Other party of judiciary believe that basis for consideration of lawful defense to be right is that it is a realistic condition where man finds himself or others exposed to present danger against self or money, and doesn't find for deterrence thereof other means that crime. This realistic case creates legal reason for justification and permission of crime. ${ }^{(4)}$

Researcher casts the opinion that considers right to lawful defense right of the victim to deter damage from himself, property or others, provided means used for deterrence of damage is proportional to the act of offense.

\section{Conditions of the right to lawful defense}

Right to lawful defense is based on two pillars of offense and defense. It is stipulated for satisfaction of offense that there is an act that threatens unlawful danger, and condition that threatens commission of crime against self or some crimes of offense of property which is defined by law. Defense shall be required and proportion to the danger which is threatened by offense. For clarification, I will handle this topic in two themes; the first is conditions of offense and the second is conditions of defense.

\subsection{Conditions of Offense:}

For offense of third parties to be considered justified, it shall satisfy specific elements, which are that it is deterrence of danger that threatens self or property, and that this offence is present and inevitable, and that this offense is illegal. Those conditions are:

3.1.1 Danger of offense of self and property:

Article (49) of Qatari penal code stipulates in paragraph (1) that right to lawful defense shall arise if the following conditions are satisfied: If defender encountered imminent danger of crime against self, property or money of his own or others, or if he believed that this danger exists, and his belief was based on reasonable causes.

Jordanian legislature expressed in article (341) of Jordanian penal code, which states that, "The following

\footnotetext{
${ }^{1}$ Mahmoud Naguib Hosny, Ibid, p. 317.

${ }^{2}$ Ibid, p. 332

${ }^{3}$ Ali Hussein Al Khalaf and Sultan Abdulkader Al Shawy, Ibid, p. 269.

${ }^{4}$ Mohamed Zaki Abu Amer, Ibid, p. 315.
} 
acts shall be deemed lawful defense:

1. Act of whoever kills another or who is inflicted by wound or any act that affects his self-defense or defense of his honor or that of others on the following conditions:

1. Pleading happens in case of occurrence of offense.

2. That offense is undue.

3. That offender can get rid of this offense only by killing, wound or effective act.

For establishment of the case of lawful defense, there shall be an act that threatens interests which are protected by penal code. Only silence or objection shall not suffice for investigation. It is not stipulated in the endangering act that it is positive act. Only objection which is considered by law to be crime shall suffice and that requires permission of the right to lawful defense and shall be subject to illegal matter which is not satisfied when offense is based on an act that threatens lawful danger. Rule in lack of legality of danger is that it threatens that crime be committed. ${ }^{(1)}$

Whoever legalizes knife to insert in defender's body or whoever puts his hand in wallet to size its contents those are undoubtedly acts that threaten offense of the right to life and safety and prejudices property right. Those rights are protected by law. ${ }^{(2)}$

Whether crime is intentional or unintentional it is same. Offender's liability shall be denied if offender lacks feeling or choice at the time of commission of harmful act because of his young age, because of insanity that inflected him, mental illness or coma that resulted from administration of narcotic or alcohol that doesn't prevent lawful defense. ${ }^{(3)}$

If offense had one of the reasons of permission, lawful defense against it shall not be acceptable because those reasons add to the acts description of permissibility of the act which strips it of illegality. Lawful defense may not be exercised against those who satisfy the state of lawful defense or state of necessity or whoever performs his duty, provided if defender exceeded the limits of permissibility he would become offender and victim may not return this offense in defense of himself.

Defender of his right to lawful defense if he caused by his provocation offense by offender and whenever the danger threatens crime, it shall not prevent satisfaction of the right to lawful defense that the accused had one of the prohibitions of penalty because this prohibition doesn't affect survival of description of criminalization actually, and doesn't prevent satisfaction of lawful defense that offender has diplomatic immunity because effect of this immunity is limited to exempting him from being subject to the authority of national judiciary, but it shall not prevent his being subject to penalties and adding the status of criminalization to the acts that violate this law. ${ }^{(4)}$

For establishment of the case of lawful defense, act of offense shall result in danger, whether real or illusive. That is, in case of illusion of crime, lawful defense may be established against him, provided illusion is based on reasonable causes that ordinary man can assess. ${ }^{(5)}$ This is what was expressed by Qatari legislature in article (50)

Right to lawful defense doesn't authorize intentional killing, unless the purpose of killing is to bar one of the following matters:

1. Act that may happen on death or serious wounds, if those fear has reasonable causes.

2. Forced dating of female or forced adultery of any person.

3. Abduction of man

4. Felonies of fire, damage or theft.

5. Night access to inhabited house or one of its appurtenances.

Jordanian legislature stipulates in article (341) thereof, paragraph two that: "Act of whoever kills or wounds another or any effective act that in defense of his property or that of others which is in his custody, provided:

1. Defense happens during embezzlement or theft that accompanies violence, or;

2. Theft leads to gross damage that can infringe will of the stolen and corrupts his choice, even if not accompanied by violence.

Dr. Kamel Al Saeed refers to act of whoever kills or wounds another or any effective act in defense of his property or that of others which is in his custody, provided that: Defense happens during embezzlement or theft of companions for violence or the stolen party and restricts his choice, even if accompanied by deletion, and that in both cases thieves and embezzlers can't be deterred and money can't be refunded without killing, murder or effective act. ${ }^{(6)}$

Therefore, killing is permissible whenever the intention of it is to bar danger of an act that raises fears of

\footnotetext{
${ }^{1}$ Ahmed Abu El Roos: Criminal intent, contribution, criminal liability, initiation and lawful defense and cause relation, Modern University Office, p. 127

${ }^{2}$ Ahmed Abdullah Beshir, ibid, p. 103.

${ }^{3}$ Mohamed Zaki Abu Amer: Ibid, p. 320.

${ }^{4}$ Ahmed Abu El Roos: Ibid, p. 127.

${ }^{5}$ Ahmed Abdullah Beshir, Ibid, p. 104.

${ }^{6}$ Kamel El Saeed: Explanation of the general provisions of penal code, comparative study, Dar Al Thaqafa for Publishing and Distribution,

$3^{\text {rd }}$ edition, Amman, 2011- 138-151.
} 
death or serious wounds whenever this fear is based on reasonable causes. For example, who walks in dark and suddenly faces gun barrel pointing to his face or suddenly shots but doesn't injure him and thinks that he is intended by kill so he initiates commission of killing in defense of himself and discovers that corpse or victim is only corpse of one of his friends who wanted to chat with him and horrify, not kill, him.

Some jurists don't clear this, and consider this case to be an example of fallacy in permission because penal liability doesn't exist by negation of the mental element of crime whether intentional or unintentional. ${ }^{(1)}$

Right to defense of property shall be restricted only by necessity of being required and suitable to offense or danger, whether the person himself or another, even if corporate person. Whoever sees a person who damages railway can prevent him by force, and in this respect he defends right of corporate person. ${ }^{(2)}$

3.1.2 That danger is imminent:

Danger shall be imminent or believed to arise and is clear from the provision of article (49) of Qatari penal code, paragraph (1), and article (341) of Jordanian penal code. Danger shall be imminent in one of the following forms:

1. Imminent danger: Imminent danger assumes that offense didn't start yet but it is in the phase of execution or at least in the phase of initiation. Threatening person shall not be required to wait in principle for his offense to justify the right to defense. It authorizes defense to him only if imminent danger threatens him. ${ }^{(3)}$

Whoever gets his pistol and loads it with bullets would pose imminent danger that authorizes defense, even if he didn't start shooting. Standard in definition of whether or not danger is imminent is standard of ordinary man. If ordinary man in those circumstances will act in accordance with the claimant's act by establishment of the state of defense; that is, in belief that danger is present, not future, and that there is no time for him to approach public authorities, the state of lawful defense exists, and judge shall authorize this, but it wasn't possible to approach public authority. This is what is expressed by Qatari legislature in article (49), paragraph two, by statement that, "It shall be difficult for defender to approach public authority in time to avoid danger."

In fact, law prescribes approaching public authorities whenever this is possible. However, law didn't impose on man to be coward. Therefore, state of lawful defense shall be existing even if it is possible to escape to avoid occurrence of danger. ${ }^{(4)}$

2. Continuous danger: It is assumed in this form of danger that it is present and exists and that it may be caused to third parties and didn't end yet. In addition, if offender shot the victim and was ready to shoot other bullets or stabbed him by knife, and prepares for other stabs, defense in this case is permissible for avoidance of inevitable damage.

If danger occurred, any reaction against offender shall be deemed type of revenge and shall not constitute state of defense. Lawful defense wasn't legalized for revenge; it was legalized to prevent offender from committing the act of offense or continuing in it so that if offense ended, lawful defense would have no existence.

3.1.3 That danger is unlawful:

Lawful defense was legalized for protection of lawful rights. If acts of offense involve illegal danger, lawful defense of them shall not be permissible. ${ }^{(5)}$

Offense that gives rise to danger shall not be based on right or order issued by authority or law because the act that results from use of right, authority or law shall be lawful and permissible even if contained danger to self or property, which leads to negation of the status of permissible act of defense. ${ }^{(6)}$

Civil servant who commits an act (such as arrest of accused) for the purpose of legal text or application of lawful order issued by the Authority may not be resisted by violence because danger that results from his act is lawful and due. Therefore, whoever is threatened by that danger shall legally assume it. If it is marred by flaw of act of employee and his act missed a condition of its justification, the act shall become illegal and danger that results from it shall be illegal. Therefore, it may be resisted by violence. ${ }^{(7)}$

A key application of this condition is the rule that there is no defense against lawful defense which is provided below, a condition for survival of the victim is that he becomes offender directly, and the party that initiates the accident may reverse this offense in defense of himself. ${ }^{(8)}$

However, we have to indicate that this danger is not required to be directed towards defender. It is the same in this case that it is directed to third parties because law authorizes every person who defends third parties, which was stipulated by Qatari legislature in article (49) of paragraph one. It is not stipulated that motivation be related to third parties. Court of Cassation confirmed in the hearing of 20/02/2012 in cassation No 28 of 2012 AD that,

\footnotetext{
${ }^{1}$ Ahmed Abdullah Beshir: Ibid, p. 104

${ }^{2}$ Samir Alya, Ibid, p. 363, and Ahmed Abdullah Beshir, Ibid, p. 103

${ }^{3}$ Ahmed Abdullah Beshir: Ibid, p. 106

${ }^{4}$ Mahmoud Naguib Hosny, Ibid, p. 230.

${ }_{5}^{5}$ Ahmed Abdullah Beshir: Ibid, p. 107.

${ }^{6}$ Ali Hussein Khalaf and Sultan Abdulkder Al Shawy: Ibid, p. 275.

${ }^{7}$ Mohamed Zaki Abu Amer: Ibid, p. 324.

${ }^{8}$ Samir Alia: Ibid, p. 361
} 
"There shall be condition of offense in the lawful defense that danger in it is present or imminent. Assessment of the facts that will result in lawful defense or denial thereof is related to the matter of the case, and the court may resolve it without constraint."

In different context, lawful defense against lawful danger may not be used as evidence. This legality is represented in that offense doesn't pose crime. For example, father who exercises his right to punishment of his son so that the latter may not use as evidence existence of lawful defense.

\subsection{Conditions of defense act:}

Right to lawful defense shall be granted to the victim as basis and shall be proved for others whether assault is committed against self or money, and whether it is gross or easy, because the court, by permission of defense, is not related to the person of the victim but the right to which offense applies. It is not stipulated for validity of defense of third parties that that third party and the victim are relatives, neighbors or intimates. In addition, his right to defense shall not elapse from others by having litigation with the victim. ${ }^{(1)}$

Right to defense shall exist only if the required conditions are satisfied in the act that gives rise to it first. If those conditions are satisfied, defense will be required and shall be reasonable.

3.2.1 Requirements of defense:

This means that criminal behavior shall be required in the means of prevention of this crime with its danger; that is, defender shall not find any way out of barring offense other than violate. That is, there is no other means by which danger can be barred. If there is another lawful method such as approaching public authority in pursuit of its protection, there will be no room here for use of violence or commission of crime. This was expressed by Qatari legislature in article (49), paragraph (2) and paragraph (3) which stipulates that, "If defender couldn't approach public authority in time to avoid danger" "that defender doesn't have any other means to bar danger."Two conditions shall be required to give rise to lawful defense.

1. Being forced to commit crime to bar danger: That is, defense shall be permitted only if the victim is not capable of barring danger except by crime that he committed. If he can bar danger by any other means than crime, defense shall be unnecessary.

2. Directing defense to source of danger: Defense shall be required only if it is directed to the source of danger, since there is no meaning for protest by lawful defense if it is directed to source foreign from danger. Whoever is attacked by a person may not by the pretext of defense direct his act to another, and whoever is attacked by dog may not leave the dog and point his defense against the dog own. ${ }^{(2)}$

3.2.2 Act shall be proportional to severity of danger:

Defense shall be proportional to severity of offense. It doesn't suffice that the act of defense be required for removal of danger. This act shall be proportional to severity of offense; that is, it shall be made to the extent necessary for barring danger. This means that missing of the condition of satisfaction means that defender has used violence to the extent that exceeds what he has to do to bar the danger that threatened him.

Scale of proportion between offense and defense shall be judicial scale left to assessment of judge in accordance with the defender's personal condition and what he believed in the surrounding conditions. Those conditions represent the product of his psychological and physical condition and his ability to take certain decision before the danger that surrounds him and the means available to him as well as severity of the danger that threatens defender which shall consider physical force of offender and motivation for commission of assault and circumstances of commission thereof. In other words, these conditions represent three elements related to defender directly in the circumstances that surrounded it, and not objective to consider approach of the normal person, according to the majority opinion. ${ }^{(3)}$

Egyptian court of cassation has judgment in this respect in which the court states that assessment of conditions of suitability of lawful defense and its requirements is a considerable matter that shall take into account personal view that considers the circumstances of motivation at the time of offense. It ruled that assessment of the force which is required for barring offense and whether it is within the right lawful defense or exceeds it is an affair of the trial court so long as the conclusion of trial court is logically consistent with the facts that were recorded in its judgment. However, if the court of cassation found that the court in its judgment proved that the appellant was in case of lawful defense and the court of cassation found anything other than this, judgment should be marred by misapplication of law.

Qatari legislature confirmed proportion in the provision of article (49), paragraph (4). It states that, "Act shall be required for barring defense and shall be proportional to it." Court of cassation noted in its ruling rendered in the hearing of 19/06/2006 of 2006 as it considered that the lawful right to defense was prescribed by law to bar every offense regardless of its severity. In consideration with proportionality of act of defense and offense shall be

\footnotetext{
${ }^{1}$ Mahmoud Naguib Hosny: Ibid, p. 226.

${ }^{2}$ Samir Alia: Ibid, p. 365 onwards.

${ }^{3}$ Samir Alia: Ibid, p. 367
} 
only after proving that there is state of lawful defense. If it is proved that this state is materialized and there is proportionality in the act of defense and offense, defender shall be entitled to acquittal. If the act exceeded offense and excess is unacceptable because this proportionality doesn't exist, the accused shall be deemed to have exceeded the limits of lawful defense and penalty shall be applied in accordance with the conditions contained in article (51) of Qatari penal code. Jordanian legislature expressed in article (341) of Jordanian penal code, which states that, "The following acts shall be deemed lawful defense:

2. Act of killing or wounding another or any act that affects his self-defense or his honor or self or that of others provided:

3. Motivation happens at the time of occurrence of offense.

\section{Restrictions of lawful defense and ruling of infringement thereof}

Occurrence of state of lawful defense and satisfaction of all its conditions by permission of the act committed by defender. Therefore, the act becomes lawful, which accordingly requires denial of penal liability, but conditions of lawful defense may be satisfied. However, the defender's act may not be proportional to the offender's act such as exceeding the limits of his defense. Therefore, motivation here is deemed to have exceeded the limits of his defense, and he shall be criminally liable for the acts that he committed, which is called transcendence of the limits of lawful defense so this topic will be discussed in two themes.

\subsection{Restrictions of lawful defense:}

If conditions of lawful defense are satisfied, defender shall comply with the restrictions defined in law and shall not exceed them. We indicate those restrictions in the following:

4.1.1 Objection of lawful defense against judicial officers:

Article (48) of Qatari penal code stipulates that there is no crime if the act is committed by civil servant in any of the following two cases:

1. Execution of order of superordinate that he shall be obey or that he believes to be his duty.

2. Enforcement of laws or belief in good faith that it is competence to enforce it.

In general, employee shall prove that he committed the act only after affirmation and investigation, and that he believed that it is legal and his belief was based on reasonable causes. Jordanian legislature expressed this as article (61) of Jordanian penal code and article (185) of the same code stipulates this meaning which states that, "Whoever attacks or violently resists employee who enforces laws or regulations shall be punished ...etc."

Article (248) of Egyptian penal code stipulates that, "Right to lawful defense doesn't permit resistance of judicial officers during performance of order based on his job duties with good faith, even if this officer exceeded the limits of his job, unless it is feared that his acts result in death or serious wounds and that fear had reasonable cause."

This means that lawful defense is banned against the employee whose work is based on application of laws and regulations but this prohibition is related to obligation of the employee with limits of his competence because justification of the act which is committed is to perform duty perform duty. ${ }^{(1)}$

There are conditions that shall be satisfied for work of judicial officer to be lawful, as follows: (2)

1. Judicial officer shall be bona fide: This means that judicial officer shall believe in validity and legality of his work. Example for lack of good faith is that judicial officer arrests a person other than the person who is to be arrested because of similarity of names and because he is his enemy or that he tortures the accused without the accused's showing of any resistance.

2. Work shall be within the scope of jurisdiction of judicial officer. That is, judicial officer shall perform work on the job duties assigned to him. If work is not originally within the limits of his jurisdiction, whoever suffers danger may bar it from himself or his property.

3. There shall be no fear that judicial officer's work results in death or sever wounds. In spite of legality of the works of judicial officer, it is feared that his acts cause death or sever wounds that, if happened, would give rise to resisting him, but without those cases there would be no motivation against the works of judicial officer.

If the above conditions which are required for legality of work of judicial officer are not satisfied, lawful defense against his works shall not be permissible. Burden of proving lack of required conditions shall be assumed by defender himself and resolution of satisfaction of those conditions shall be attributed to the court. ${ }^{(3)}$

Qatari legislature addressed infringement in good faith in article (51) that stipulated that, "if a person exceeded in good faith the limits of lawful defense by using for barring offense force that exceeds the extent that had to be used by ordinary person if he was in his circumstances and without intending to cause severer harm

\footnotetext{
${ }^{1}$ Samir Tawfiq Al Magaly, Penal Code, Ibid, p. 172.

${ }^{2}$ Mahmoud Naguib Hosny, Ibid, p. 249.

${ }^{3}$ Ali Hassan Al Khalaf and Sultan Al Shawy: Ibid, p. 277.
} 
which gives rise to defense, judge may, if the act is felony, consider the person who be excused and shall be sentenced to the penalty of misdemeanor instead of the penalty prescribed in law, and to consider it a diluted condition if act is misdemeanor."

From this text, Qatari legislature appears to have repaired the infringement that happens in good faith. It is noted that this article authorized judgment of the penalty of misdemeanor if the act committed by defender is felony, but if the act is misdemeanor, judge may consider it diluted condition, but condition of this provision is that it shall be applied only in case of good faith. According to law, this matter shall be subject to judge's discretion. The order of dilution was made discretionary by Qatari legislature.

The Egyptian Court of Cassation ruled in judgment that, "If infringement is committed in good faith, this shall be worthy of dilution and shall be considered sheer substantive matter that trial court shall exclusively resolve."

However, we have to indicate that the previous attitude adopted by Qatari legislature is the same attitude of the corresponding Egyptian one.

4.1.2 Restriction on the force of the right to defense

Defender in case of lawful defense shall have the right to use force to the extent required for barring the offense against him so long as conditions of defense are met.

1. Crimes against persons: Qatari and Jordanian legislatures stipulate that crimes of killing of all types permit lawful defense. Regardless of severity, simplicity or seriousness thereof, this is conditional upon necessity to satisfy the mandatory conditions and proportionality condition. Right to lawful defense arises against any crime of killing, but satisfaction of restriction condition shall be materialized between offense and defense. ${ }^{(1)}$

2. Crimes committed against properties: Jordanian legislature limited crimes against properties to crimes of theft and embezzlement. Therefore, lawful defense against other crimes such as fraud, abuse of trust, fraud in transactions, sabotage, usurpation of property and crimes of setting properties of others on fire shall not be permitted. ${ }^{(2)}$ Concerning Qatari legislature, it had different approach from that of Jordanian legislature. There was term for establishment of lawful defense against any crime of properties was in contrast to Jordanian legislature that defined the crimes of properties whereby state of lawful defense is proved as limitation.

\subsection{Rule of infringement of lawful defense}

Condition for materialization of the right to lawful defense is that the act of defense is proportional to the act of offense so that defender uses only the necessary deal of power to bar the danger in which case the act committed by defender becomes permissible. However, defender may exceed his right to defense by using force more than required for defense to prevent offense. In this case, there would be example of exceeding the right to lawful defense $^{(3)}$. This was expressed by Qatari legislature in the provision of article (49) of Qatari penal code in paragraph (4)

Conditions for exceeding the limits of lawful defense: ${ }^{(4)}$

1. When the defender's act is intentional: As when he is threatened with battery by ordinary stick and blocked this shot by shooting fire or fatal stab, while only battery shall suffice.

2. Danger in it is illusive: Basis of belief of defender in good faith that he encounters state of danger, although reality is not the same, as if he saw defender holding knife and moving towards him and thought that he aims at stabbing him then he battered him by stick on his hand that led to break of hand and discovered later that the knife owner came to sharpen it at knife repairer near to defender.

It is stipulated for satisfaction of state of lawful defense in accordance with article (341) of the penal code that: 1- Act happens in defense of self or honor. 2- Motivation happens at the time of offense. 3- Offense is not due. 4-Offender can't get rid of offense except by killing, wound or effective act. If it is proved that victim can get rid of offense that he suffered without resorting to killing or wound, his act shall not be lawful defense. ${ }^{(5)}$ (Penal Court of Cassation, No 668/2007 and 55/73). Whereas the fact that was concluded by Supreme Criminal Court that there is guessing of the accused's motivation who fall to earth as a result, so it overlapped with Emad by hands and the accused held pistol and removed it and took the sections and during escape of the Emad the accused shot bullet that inflicted Emad in his left shoulder. Whereas this incident proves that the accused could have barred the offense that he suffered which is represented in hand quarrel by not shooting bullets in the direction of Emad so long as overlapping by hand doesn't constitute danger and threat to the accused's life.

Infringement of lawful defense is based on two elements: Material Element: This element is represented in

\footnotetext{
${ }^{1}$ Nizam Al Magaly, Ibid, p. 188

${ }^{2}$ Nizam Al Magaly, Ibid, p. 191

${ }^{3}$ Ali Hassan Al Khalaf and Sultan Al Shawy: Ibid, p. 280

${ }^{4}$ Sultan Al Shawy: Ibid, p. 282

${ }^{5}$ Decision of Jordanian (Penal) Court of Cassation, No 668/2007 and 55/73)
} 
prejudice to the offender's interest to the extent that exceeds the danger that threatens the victim, and it is, as said before, happens when there is no condition of proportionality by using deal of violence that exceeds what is required for barring danger to make defense illegal and to fall in the grip of general rules of criminalization and punishment, and its rule is that intentional liability takes place whenever he intentionally exceeds the limits of defense, such as the person who defends himself against child who wanted to kick him so he severely battered him to death while it is proved that he perceives and knows that he exceeded the limits of defense. In such case, intentional liability is proved for the crime of intentional battering that led to death. In additional, intentional liability shall be established if defender exceeded the limits of lawful defense as a result of error, as if the person wanted to block offense that he suffered from another person and shot for this purpose bullet that inflicted and injured anther because he didn't accurately shoot it if it is proved that he could have done it in the circumstances in which he was found and in accordance with his capacities to assess the scope of danger and to properly bar it.

(1) The second is a psychological element represented in the condition of good faith. This shall be satisfied if infringement of limits of proportionality without intention by perpetrator. This was expressed by Qatari legislature in article (51) of Qatar penal code. There is no doubt that there is no liability in this case because he didn't have the freedom of will and distinction in the way that establishes any crime because of lack of mental element, such as the case of whoever initiates insult of another in front of his family and people and gossips his honor or slabs him without reason so he starts throwing glass from which he had beverage and inflicts him with permanent disability. If perpetrator of crime overused the right to lawful defense he shouldn't be punished if he committed the act in revolution of apex emption that removed his power of conscience and will. ${ }^{(2)}$

It is stipulated for materialization of excess of the limit of lawful defense that there is right to defense which requires substantiation of offense with its three conditions which are to have an act that threatens unlawful danger and that danger is present and results from crime against self or again property, which is defined by law. In addition, condition of necessity shall be satisfied in defense. If one of the conditions is not satisfied, the act shall be deemed crime in accordance with the general rules. If condition of proportionality is not denied in defense, it shall exceed the limit of lawful defense so infringement of lawful defense may not be investigated unless right to this defense is proved in principle. If there is doubt in proving infringement, it shall be interpreted in interest of the accused. Statement that he was in state of lawful defense and lawful defense may be satisfied by the accused and there would be injuries that happen to the victim, then he shall exceed the lawful defense afterwards. In this case, the accused shall be held accountable for the injuries that he caused to the victim in the phase of infringement only. ${ }^{(3)}$

We shall not confuse infringement and illusive danger. The first shall extend to infringement of the condition of proportionality. The second shall extend to wrong belief of the accused that there is a condition of infringement. An example of this infringement is what was ruled by the Court of Cassation that if perpetrator shot fire bullet against thieves to prevent them from escaping after commission of theft which is not considered felony of killing one of them, he shall not be deemed offender except to the extent that exceeded his right to lawful defense. ${ }^{(4)}$

\section{Proving lawful defense and effect of it}

Satisfaction of the state of lawful defense and completion of all its conditions shall result in permission of the act of defense; that is, it becomes lawful act and perpetrator shall not be held liable on the civil or penal side. However, defender shall prove satisfaction of those conditions and the court shall be satisfied with existence of justification for lawful defense. To clarify this, this topic will be investigated as follows:

\subsection{Proof of the right to lawful defense:}

Defendant may recognize the charges brought against him and plead that he was in state of lawful defense. It is not stipulated for invocation of defense that it comes with the express term thereof in which case the trial court shall indicate its elements to verify substantiation of the facts of lawful defense or denial thereof, and trial court shall have absolute authority in this respect.

Trial court shall determine whether it is possible for defender to resort to police authority and whether or not he can bar offense by any other means, and that the defender's purpose or intention was to bar offense by means or another or that the defender's purpose or intent was to bar offense or revenge, and the accused's failure to raise it whether he is in state of lawful defense, the court shall investigate the lawful defense in two cases as follows:

First: When facts of the case are explained in that there is state of lawful defense: The court shall address at its initiative investigation of the state of lawful defense and shall prove or deny it even if the accused didn't; plead this before it even if the accused confirmed commission of the act.

Second: When the accused invokes the lawful defense or excuse of infringement, the court shall address this pleading by response and trial court shall have the full authority to assess the facts on which the state of lawful

\footnotetext{
${ }^{1}$ Mohamed Abu Amer: Ibid, p. 235, and Ahmed Beshir, Ibid, p. 114.

${ }^{2}$ Sultan Al Shawy: Ibid, p. 311

${ }^{3}$ Ahmed Abul Roos: Ibid, p. 139

${ }^{4}$ Mahmoud Naguib Hosny: Ibid: p. 349
} 
defense is based or excuse of infringement. There is be no control over the trial court by the court of cassation in this respect unless the trial court misinterprets or misapplies law. Examples of misinterpretation of law is that court adds condition that wasn't required by law or abates condition that was required by law. Examples of misapplication of law is that the court doesn't address the state of lawful defense when the facts of the case are determined. In addition, the court established it by the state of lawful defense or explains substantiation thereof or disregards inclusion of the accused's motivation for establishment of the state of lawful defense or excuse of infringement, or to provide pleading without response thereto, or respond thereto by flawed or contradictory reasons.

\subsection{Effect of the right to lawful defense:}

Whenever the right to lawful defense is satisfied and defender complied with its restrictions, crime that was committed by perpetrator shall be justified, and shall become as such lawful act that doesn't give rise to any penal or civil liability. According to substantive nature of the reasons for justification, effect of permission shall extend to act which is related to the original act, so that it becomes permissible as if defender used in his defense licensed weapon, and his liability and confiscation shall be denied.

Defender may err in spite of satisfaction of the conditions of defense and he may inflict a person other than the offender who was thought to be source of offense, as if he encountered attack in the dark and shot fire at a person who walks behind him in belief that he is the offender who would have escaped. He may err also in shooting so the act would be committed against pedestrian. In these two cases, there is unintentional penal error against defender, unless this error is based on reasonable causes uncontrollable and out of his liability, and the act shall be justified. ${ }^{(1)}$ This was expressed by Qatari legislature in article (51): "If the person exceeded in good faith the limits of lawful defense, by using for deterrence of offense force that exceeds the limit that was used by ordinary person if found in his circumstances and without intending to cause severer harm that requires defense, judge may, if the act is felony, consider the person to be excused and indict him by punishment of misdemeanor instead of penalty which is prescribed by law, and to consider it diluted condition, if act is misdemeanor. "

If defender found himself forced to prejudice right of a third party to be able to defend himself, as if he seized policeman pistol to defend himself against offender, or damaged front of store for sale of shooting arms to take gun by which he defends himself, the rule is that those acts are unjustified because they weren't tended to the source of danger, but they constitute reasons for case of necessity whenever their conditions are satisfied, particularly because danger is gross. ${ }^{(2)}$

\section{Conclusion}

Right to lawful defense is a reason for justification. Qatari legislature authorized the right to lawful defense against any offense of self or property, in contrast to Jordanian legislature that defined the crimes that constitute offense of property, as limitation, and were defined in the crimes against money (theft and embezzlement).

Case of necessity differs from the case of lawful defense since necessity is considered to be prohibition of penal liability. Therefore, materialization of it doesn't relieve the party who used it from civil liability, while the right to lawful defense is considered reason for justification and act of defense if it is within the controls and limits that consider it lawful act. Therefore, civil liability is not satisfied against the party who uses the right to lawful defense:

If the case of lawful defense is satisfied and defender exceeded his limits by lack of proportionality of the act of defense with the offense that was committed by offender, infringement shall either in good faith and its ruling was stipulated explicitly by Qatari legislature. If infringement is intentional or in bad faith, the person who committed that act shall be held liable for intentional crime. Therefore, this research recommends as follows:

1. Qatari legislature stipulates that state of lawful defense against danger which is believed to be done by defender, but researcher finds opposite of this in that the risk by which the state of lawful defense is established. As mentioned in legal jurisdiction, lawful defense shall be established only against the present danger so how it can explicitly stipulate the danger which is believed by defender so there shall be present risk for establishment of the state of lawful defense.

2. Qatari legislature restricted the judge's authority in case of infringement in good faith and it would have been better to leave assessment of relief to trial judge.

\section{References}

First: Books

Ahmed Abdullah Beshir: General Criminal Law, Part I in Crime, Faculty of Law, Al Azhar University, 1998.

Ahmed Abu El Roos: Criminal intent, contribution, criminal liability, initiation and lawful defense and cause

\footnotetext{
${ }^{1}$ Samir Alia: Ibid, p. 369

${ }^{2}$ Mahmoud Hosny: Ibid, p. 412
} 
relation, Modern University Office, no publication year.

Ahmed Fathi Sorour: Al Wassit in Penal Code, General Section, Dar Al Nahda Al Arabia, $6^{\text {th }}$ edition, 2015 AD. Kamel, Al Saeed: Explanation of General Rules in the penal code, Comparative Study, Dar Al Thaqafa for Publishing and Distribution, $3^{\text {rd }}$ Edition, Amman, 2011.

Mahmoud Naguib Hosny: Explanation of Penal Code, General Section, Dar Al Nahda Al Arabia, 1975 AD, Beirut. Mohamed Sobhy Negm: Penal Code, General Section, General Theory of Crime, $1^{\text {st }}$ edition, Dar Al Thaqafa for Publishing and Distribution, Amman, Jordan, 2000.

Mohamed Zaki Abu Amer: Penal Code, General Section, Dar Al Gamaa Al Gadida for Publishing, 1996 Edition.

Nezam Tawfiq Al Magaly: Explanation of Penal Code, General Section, Dar Al Thaqafa for Publishing and Distribution, 2005, Amman.

Samir Alya: Fundamentals of Penal Code, General Section, Comparative Study, University Establishment for Study, Publishing and Distribution, 1994.

Sultan Abdulkader Al Shawy: General Principles of Penal Code, Republic of Iraq, Ministry of Higher Education and Scientific Research, 1982.

\section{Second: Laws:}

- Qatar penal code No (11) of 2004

- Jordanian penal code, as amended 